\title{
THEORETICAL AND PRACTICAL ASPECTS REGARDING THE CANCELLATION OF ABUSE CLAUSES
}

\author{
Mariana Rodica ȚÎRLEA \\ "Dimitrie Cantemir" Christian University Bucharest, Romania \\ rodicatirlea10@yahoo.ro
}

\begin{abstract}
Interest and commissions are important sources of revenue for credit institutions. Among the causes generating abusive clauses are the interest, interest rates and commissions charged to loans to customers by creditors. Theory and practice have shown that these abusive clauses are unlimited. Effective knowledge of abusive clauses is only one of the customer protection measures. Of course, only their knowledge does not completely solve the problem, but will determine the orientation of creditors in finding more subtle abusive clauses. From a multidisciplinary perspective, the Study is structured in two parts: Part I, follows aspects of concrete identification of the types of sources of abusive clauses on a specified case and Part II materializes in the technical-applicative presentation of the methods used to quantify the differences in the amounts paid by the client in addition, generated by the existence of abusive clauses in the credit agreement he concluded with the creditor. The results of the first part confirm: Hypothesis 1, regarding the existence of abusive clauses in the investigated case; Hypothesis 2, regarding the identification of the sources generating abusive clauses that materialize in the interest rate, interest and bank fees; Hypothesis3, referring to the analytical grouping by types of the sources causing abusive clauses.
\end{abstract}

Keywords: Credit, interest, interest rate, instrumentation commission, management commission, initial credit granting commission, early repayment commission, credit non-use commission

\section{Introduction}

The concept of abusive contractual clause implies a: „contractual clause that has not been individually negotiated with the consumer and creates contrary to the requirements of good faith, by itself or together with other provisions of the contract, to the detriment of the consumer a significant imbalance between rights and obligations"[1]. We deduce from this definition that, in order to qualify a contractual clause in a contract, in the category of abusive clauses, it must cumulatively meet several requirements:

To be included in the content of the contract[4], its aspects of adhesion that will be considered:

- The circumstances of concluding the contract;

- subject of the contract;

- the totality of the clauses included in the credit agreement;

- the extent to which the clauses are presented in a simple, clear, intelligible manner

- different effects or non-existence of negotiating clauses; the creditor acted in good faith in relation to the legitimate interests of his client;

- encouragement of the creditor regarding a 
clause that could benefit the customer;

1. Let that clause result:

- it was not negotiated with the creditor;

- there is no possibility to be analysed

before signing the credit agreement;

- in the event that the creditor claims that a clause has been negotiated, he has the task of proving;

- even if at a clause certain elements can be demonstrated to have been negotiated in the manner of individual negotiation this does not preclude the evaluation of the contract in the event that this contract is a contract of accession;

\section{Practical aspects on a specified case}

The practical aspects [4], aim at identifying the interests, commissions and rates on the contracted credit that generated significant contractual imbalances and the recalculation of the fixed interest and the commissions applied by the creditor to a credit contracted by a legal person of the nature of a credit line. The contracted loan was in the amount of 100,000 lei under the conditions established by the credit agreement, which provided in the chapter on interest and commissions that: the interest related to the loan is the interest charged at the date of signing the contract, interest at $9 \%$ per annum; the method of calculating the interest consists in applying the percentage of $9 \%$ to the loan balance starting from the date of granting the loan and until the full repayment of the loan. In the following year, when the credit is contracted, the credit institution proceeds to conclude the first addendum amending the credit agreement, which stipulates that, the method of calculating the annual interest rate changes [4]. This change assumes that the interest rate changes in relation to the interest rate used ROBOR. During a period of nine years, the client receives eight additional documents, which have the effect of changes to the initial credit agreement. The additional documents [4], generated changes as follows:

A. At the interest and the interest rate, the changes made by the additional documents are presented in table number 1 :

Table 1 Statement of changes to the credit agreement by additional documents

\begin{tabular}{|c|c|c|c|}
\hline No. & Year & $\begin{array}{c}\text { Additional } \\
\text { amending } \\
\text { act[4] }\end{array}$ & Amendments to the addendum[4] \\
\hline 1. & 2008 & No.1 & fixed interest BUBOR 1 M $+1.7 \%$ per year \\
\hline 2. & 2009 & No.2 & fixed interest rate $25 \%$ per year, indexable \\
\hline 3. & 2009 & No.3 & fixed interest rate ROBOR1M $+4 \%$, indexable \\
\hline 4. & 2010 & No.4 & fixed interest rate ROBOR1M $+4 \%$, indexable \\
\hline 5. & 2011 & No.5 & fixed interest rate ROBOR1M $+4 \%$, indexable \\
\hline 6. & 2012 & No.6 & fixed interest rate ROBOR1M $+4 \%$, indexable \\
\hline 7. & 2013 & No.7 & fixed interest rate ROBOR1M $+4 \%$, indexable \\
\hline
\end{tabular}

Source: Author [4], processed based on additional documents to the credit agreement

B. At the level of commissions, the changes occurred from the moment of instrumentation and analysis of the documents and until the date of early repayment of the loan, a number of 20 commissions were established for the client. The commissions calculated and paid by the client [4], are materialized in:

1. commission for instrumentation and analysis of documents when granting the loan;

2. the credit granting commission;

3. instrumentation and analysis 
commission related to the additional act number 1;

4. initial commission related to additional act number 1 ;

5. instrumentation and analysis commission related to the additional act number 2;

6. initial commission related to additional act number 2 ;

7. instrumentation and analysis commission related to the additional act number 3;

8. initial commission related to additional act number 3 ;

9. instrumentation and analysis commission related to the additional act number 4;

10. initial commission related to additional act number 4 ;

11. instrumentation and analysis commission related to the additional act number 5;

12. initial commission related to the additional act number 5;
13. instrumentation and analysis commission related to the additional act number 6 ;

14. initial commission related to additional act number 6 ;

15. instrumentation and analysis commission related to the additional act number 7 ;

16. initial commission related to additional act number 7 ;

17. early repayment fee;

18. non-use commission;

19. Account maintenance fee;

20. the commission for operations occasioned by the replenishment of the current account;[4].

We notice that it is not justified:

- the commission for not using the credit

- the instrumentation and analysis

commissions related to the additional documents;

- initial commission related to the 7 additional acts;

- management fee.

Table 2 Statement of fees charged during the course of the loan

\begin{tabular}{|c|l|c|c|}
\hline No & \multicolumn{1}{|c|}{$\begin{array}{c}\text { Type of } \\
\text { commission [4] }\end{array}$} & $\begin{array}{c}\text { Percentage } \\
\text { share/ } \\
\text { fixed } \\
\text { amount [4] }\end{array}$ & $\begin{array}{c}\text { The method of calculating the commission } \\
\text { applied by the creditor [4] }\end{array}$ \\
\hline $\mathbf{1 .}$ & $\begin{array}{l}\text { Instrumentation } \\
\text { commission }\end{array}$ & $150 \mathrm{RON}$ & Fixed amount at the date of document analysis \\
\hline $\mathbf{2 .}$ & $\begin{array}{l}\text { Initial award } \\
\text { commission }\end{array}$ & $1 \%$ & Percentage Applied to the total value of the loan \\
\hline $\mathbf{3 .}$ & $\begin{array}{l}\text { Instrumentation } \\
\text { commission }\end{array}$ & $150 \mathrm{RON}$ & Fixed amount at the date of document analysis \\
\hline $\mathbf{4 .}$ & $\begin{array}{l}\text { Initial commission } \\
\text { Additional act no.1 }\end{array}$ & $1 \%$ & Percentage applied to the credit balance \\
\hline 5. & $\begin{array}{l}\text { Instrumentation } \\
\text { commission }\end{array}$ & $150 \mathrm{RON}$ & Fixed amount at the date of document analysis \\
\hline $\mathbf{6 .}$ & $\begin{array}{l}\text { Initial commission } \\
\text { Additional act no.2 }\end{array}$ & $1 \%$ & Percentage applied to the credit balance \\
\hline 7. & $\begin{array}{l}\text { Instrumentation } \\
\text { commission }\end{array}$ & $150 \mathrm{RON}$ & Fixed amount at the date of document analysis \\
\hline $\mathbf{8 .}$ & $\begin{array}{l}\text { Initial commission } \\
\text { Additional act no.3 }\end{array}$ & $1 \%$ & Percentage applied to the credit balance \\
\hline 9. & $\begin{array}{l}\text { Instrumentation } \\
\text { commission }\end{array}$ & $150 \mathrm{RON}$ & Fixed amount at the date of document analysis \\
\hline
\end{tabular}




\begin{tabular}{|c|c|c|c|}
\hline 10. & $\begin{array}{l}\text { Initial commission } \\
\text { Additional act no. } 4\end{array}$ & $1 \%$ & Percentage applied to the credit balance \\
\hline 11. & $\begin{array}{l}\text { Instrumentation } \\
\text { commission }\end{array}$ & $150 \mathrm{RON}$ & Fixed amount at the date of document analysis \\
\hline 12. & $\begin{array}{l}\text { Initial commission } \\
\text { Additional act no. } 5\end{array}$ & $1 \%$ & Percentage applied to the credit balance \\
\hline 13. & $\begin{array}{l}\text { Instrumentation } \\
\text { commission }\end{array}$ & $150 \mathrm{RON}$ & Fixed amount at the date of document analysis \\
\hline 14. & $\begin{array}{l}\text { Initial commission } \\
\text { Additional act no. } 6\end{array}$ & $1 \%$ & Percentage applied to the credit balance \\
\hline 15. & $\begin{array}{l}\text { Instrumentation } \\
\text { commission }\end{array}$ & $150 \mathrm{RON}$ & Fixed amount at the date of document analysis \\
\hline 16. & $\begin{array}{l}\text { Initial commission } \\
\text { Additional act no. } 7\end{array}$ & $1 \%$ & Percentage applied to the credit balance \\
\hline 17. & $\begin{array}{l}\text { Early repayment } \\
\text { fee }\end{array}$ & $4 \%$ & Percentage applied to the repaid value of the loan \\
\hline 18. & $\begin{array}{l}\text { Account } \\
\text { Maintenance Fee }\end{array}$ & $\begin{array}{c}15 \\
\text { RON/Mont } \\
h\end{array}$ & Fixed amount/month \\
\hline 19. & $\begin{array}{l}\text { Non-use } \\
\text { commission }\end{array}$ & $4 \%$ & $\begin{array}{l}\text { Percentage applied to the unused value of the } \\
\text { credit line ceiling }\end{array}$ \\
\hline 20. & $\begin{array}{l}\text { Fee for current } \\
\text { account supply }\end{array}$ & $10 \mathrm{RON}$ & Fixed amount/operation \\
\hline
\end{tabular}

Source: Author [4], processed based on the contract and additional documents

\section{Conclusions}

One year after the date of the contract, the creditor submits the first addendum to the credit agreement, which provided that the annual interest rate would be: fixed interest: BUBOR1M $+1.7 \%$ per year.

The specialized literature specifies the meaning of BUBOR, as an average interest rate. These are the situations in which deposits are placed on the interbank market, with maturities of: $1,3,6,9,12$ months or even for a week. Subsequently, starting with the third year, BUBOR is replaced by ROBOR. We note that at the bank's fixed interest rate, it represents the value expressed as a percentage, which is added to the bank's interest rate applied to a loan. The interest rate remains fixed during the contract, and the interest rate changes depending on the ROBOR. The contract provided for a fixed interest rate of $1.7 \%$ year, which was subsequently not respected by the creditor. The determination of the differences involved taking into account the fixed interest rate of $1.7 \%$ and the ROBOR interest for the reference period. With regard to the commissions charged, we note that some of them are not justified. These commissions materialize in:

1. credit non-use fee

2. the instrumentation and analysis commissions related to the additional documents;

3. initial commission related to the 7 additional acts;

4. management fee.

Compared to the provisions of Article 13 of Law 140, point d), [3], ,the price or the method of calculating the price or the existence of a specific price advantage" are subject to incorrect commercial practices. 


\section{References List}

[1] Băieșu, A., \& Plotnic, O (2014), „Consumer protection law”, CEP USM, ISBN 978-9975-71511-9, p. 122.

[2] Civil Code of the Republic of Moldova, updated.

[3] Law 140 of 28.07.2011, entered into force on 01.01.2012 after Băieșu, A., \& Plotnic, O (2014), „Consumer protection law”, CEP USM, ISBN 978-9975-71-511-9, p. 213.

[4] Țîrlea, M.,R., „Extrajudicial accounting expertise report” . 